\title{
SURVEY OF OLIVE LEAF SPOT IN NEW ZEALAND
}

\author{
A.J. MACDONALD ${ }^{1}$, M. WALTER ${ }^{2}$, M. TROUGHT ${ }^{1}$, \\ C.M. FRAMPTON ${ }^{1}$ and G. BURNIP ${ }^{2}$ \\ ${ }^{1}$ Lincoln University, P.O. Box 84, Lincoln, New Zealand \\ ${ }^{2}$ HortResearch, P.O. Box 51, Lincoln, New Zealand
}

\begin{abstract}
Olive leaf spot (OLS) or peacock spot, caused by the fungal pathogen Spilocaea oleagina, can cause reduced growth and yield in olive trees (Olea eurapaea). Investigations were carried out during December 1999 and January 2000 to measure the prevalence and severity of olive leaf spot in the Auckland, Waiheke Island, Wairarapa, Marlborough and Canterbury growing regions of New Zealand. The susceptibility of six cultivars (Barnea, Manzanillo, Frantoio, Leccino, Nabali and Souri) to OLS was assessed. OLS was found in all study areas with Auckland and Marlborough the worst affected. OLS appeared to be particularly severe on trees that were growing in sheltered parts of an olive grove. Severity increased with age and a correlation between prevalence and severity was found. Souri and Nabali were the worst affected cultivars while Frantoio and Leccino were least affected.

Keywords: Peacock spot, Spilocaea oleagina, Cycloconium oleagina, disease prevalence, disease severity.
\end{abstract}

\section{INTRODUCTION}

The olive industry in New Zealand is relatively new, but considerable interest has been developed over the last 12 years with olive trees being planted from Central Otago to Northland. Olive production is affected by olive leaf spot (OLS). The disease, also known as peacock spot, is caused by the fungus Spilocaea oleagina Castagne (Hughes) (=Cycloconium oleagina) which lives parasitically on olive (Olea eurapaea L.) leaves, except on susceptible cultivars, where fruit and fruit peduncles may also be infected (Graniti 1993).

Initially, symptoms are found on the upper surface of the leaf, where lesions may be inconspicuous. Leaves soaked in $5 \% \mathrm{NaOH}$ solution for $1-2$ minutes at $50-60^{\circ} \mathrm{C}$ (Shabi et al. 1994) can enhance detection of the spots at this stage. Lesions expand slowly, forming dark green round spots from 2-15 mm in diameter. Spots from adjacent infections may coalesce. The spots turn dark brown and become necrotic with age, often surrounded by concentric yellowish or pale brown haloes, hence the name peacock spot.

OLS is more serious in humid olive growing areas of the world where extended periods of wet weather favour disease development (Teviotdale and Sibbett 1995a). Infection requires that leaves remain wet or in a nearly saturated atmosphere for 1-2 days, depending on the temperature (Graniti 1993). Infection generally occurs during wet periods from autumn through winter to spring when inoculum levels from lesions is highest (Azeri 1993; Viruega and Trapero 1999). Infections then become evident in spring with new lesions developing and causing premature leaf drop. In hot, dry weather conditions the growth of the pathogen is limited (Graniti 1993), the disease is inactive (Teviotdale and Sibbett 1995b) and infection seldom occurs (Laviola and Scarito 1993).

Younger, less cutinised leaves are more susceptible than older leaves (LópezDoncel et al. 1999). The margins of OLS lesions expand laterally into adjacent healthy tissue, where conidia are produced. These conidia are the principle inoculum source causing subsequent infection (Shabi et al. 1994) and are dislodged and dispersed over 
short distances by rain (Laviola and Scarito 1993). Although most infected leaves are shed, some remain, and lesions on these become sources of inoculum (Teviotdale and Sibbett 1995a). Limited wind dissemination also occurs in the absence of rain, if relative humidity is over 70\% (De Marzo et al. 1993). Other vectors, such as flying insects may be responsible for spreading OLS over greater distances (Laviola and Scarito 1993; Lops et al. 1993). De Marzo et al. (1993) have reported that insects can feed on S. oleagina and spread conidia by carrying them on body surfaces or by allowing them to pass without damage through their alimentary canal (De Marzoet al. 1993).

Crop losses (up to 20\%) arise mostly from defoliation of infected trees, but recurrent infections cause poor growth and dieback of defoliated branches, further reducing fruit yield (Azeri 1993; Graniti 1993). Heavy defoliation may also cause a delay in ripening and decrease in oil yield (Graniti 1993).

Regardless of material, application rate or number of applications, copper containing fungicides will control OLS when disease risk is low (Teviotdale et al. 1989a,b). However, regular annual treatment is required to prevent disease build-up in the grove, as high disease levels may be difficult to reduce (Teviotdale and Sibbett 1995a,b).

The aim of this survey was to evaluate the prevalence and severity of OLS in New Zealand for five different growing regions: Auckland, Waiheke Island, Wairarapa, Marlborough and Canterbury.

\section{MATERIAL AND METHODS}

The survey was conducted during summer 1999/2000. Four to seven olive groves were selected in each of five growing regions (Table 1). Prevalence and severity of OLS was surveyed in established groves with trees preferably older than 3 years.

TABLE 1: Growing region, number of groves visited and dates for OLS survey.

\begin{tabular}{lcr}
\hline Growing Region & No of Groves & \multicolumn{1}{c}{ Date } \\
\hline Canterbury & 3 & $9-13$ December 1999 \\
& 1 & 22 December 1999 \\
Marlborough & 3 & 4-5 February 2000 \\
Wairarapa & 6 & 15-19 December 1999 \\
Auckland & 5 & 9-11 January 2000 \\
Waiheke Is. & 4 & 16-18 January 2000 \\
\hline
\end{tabular}

The surveyed groves included six cultivars of varying ages. Four cultivars (Barnea, Manzanillo, Frantoio and Leccino) were selected because they were common to the five regions surveyed. Two cultivars (Souri and Nabali) were selected because of their known susceptibility to OLS.

Twenty randomly sampled trees of each cultivar were examined in each grove and assigned a numbered identification tag. If fewer than 20 trees of one cultivar existed in a grove then all trees were selected. On trees approximately $2 \mathrm{~m}$ and higher, 20 branches containing 20 leaves (400 leaves in total) were examined for OLS infection. On trees smaller than $2 \mathrm{~m}$, ten branches or 200 leaves were examined. Branches were randomly selected from the lower south side of the tree. Only leaves from last season's growth were assessed.

Leaves with visible symptoms were collected for disease identification and severity assessments in the laboratory. From these leaves a sub-sample (25 leaves) was taken at random to evaluate the severity of peacock spot by visually estimating the area $(\%)$ covered with lesions and counting the number of lesions on each leaf. Severity was recorded as $5,12.5,25,37.5,50,75,90$ and $100 \%$ area covered with OLS. The number of lesions was graded 1 (1 lesion), 2 (2 lesions), 3 (3-5 lesions), 4 (6-10 lesions) or 5 $(11+$ lesions $)$. 


\section{RESULTS AND DISCUSSION}

The olive industry is relatively new in New Zealand with most of the groves planted in the last 3-4 years. An overview of the number of trees assessed by cultivar and area can be seen in Fig. 1. From the trees examined, 39\% were found to have OLS. From the total amount of leaves, $9.5 \%$ showed symptoms with a median of 2 lesions covering $22 \%$ of the leaf area.

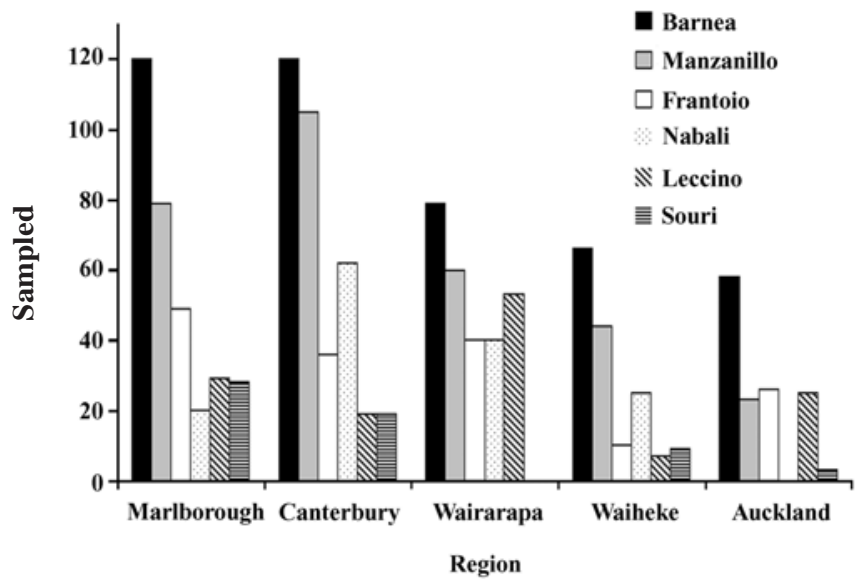

FIGURE 1: The number of trees sampled for each cultivar in each region.

\section{Effect of tree age}

The prevalence of OLS significantly increased with tree age $\left(\chi^{2}=92.3\right.$, df $=2$, $\mathrm{P}<0.001$; Fig. 2). Overseas epidemiological studies are mostly conducted on established mature orchards (Viruega and Trapero 1999). As trees age, canopy size and canopy density increase, creating more shelter and increasing the humidity within and between trees. This makes the grove more suitable for OLS infection (Teviotdale and Sibbett $1995 \mathrm{a}, \mathrm{b})$. Younger trees tend to have a reduced canopy density making the tree less suitable for peacock spot to become established.

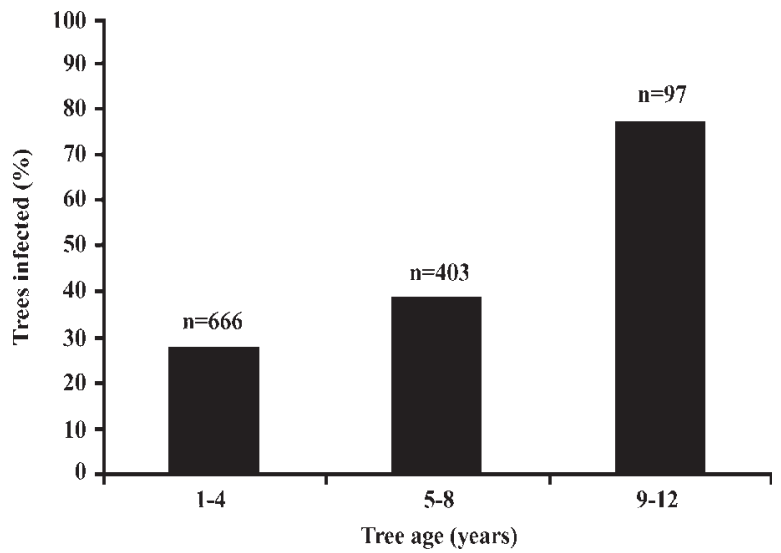

FIGURE 2: Effect of tree age on OLS prevalence. Data was pooled across all cultivars and all sites; $n$ denotes the total number of trees assessed in each age group. Trees where growers could not identify age were omitted. 


\section{Effect of region}

From the five regions studied; Auckland and Marlborough showed the highest percentage of trees infected with OLS followed by Canterbury, Wairarapa and Waiheke $\left(\chi^{2}=343.4\right.$, df $=4, \mathrm{P}<0.001$; Fig. 3$)$. Of the regions studied, Auckland is warm, with high rainfall and humidity (Table 2). This could explain the high prevalence of OLS in trees and on leaves. Considering the regional proximity of Waiheke Island to Auckland, it may also be expected that in Waiheke a high prevalence of OLS could be found. However, regional variations in climate, the isolated location of the island and lack of exposure to OLS may combine to reduce infection pressure. Also, differences in management (e.g. fungicide application, pruning, shelter) (Teviotdale and Sibbett 1995a,b) could contribute to the lower tree infection on Waiheke Island. The high proportion of older trees, sheltered sites and an unusually wet season (B. West, pers. comm.) in Marlborough may have contributed to a relatively high prevalence of OLS, despite the low long-term rainfall pattern (Table 2). With a high proportion of middle aged trees (75\% of trees in the age group of 5-8 years) in Canterbury, one would also expect a higher proportion of trees infected. However, both Canterbury and Wairarapa groves are more likely to be exposed to dry, windy conditions.

TABLE 2: Summary of climatological data from the regions sampled (Anon. 1980).

\begin{tabular}{lccc}
\hline Region & $\begin{array}{c}\text { NZ Met. } \\
\text { Station }\end{array}$ & $\begin{array}{c}\text { Annual rainfall } \\
(\mathrm{mm})\end{array}$ & $\begin{array}{c}\text { Mean monthly } \\
\text { temperature }\left({ }^{\circ} \mathrm{C}\right)\end{array}$ \\
\hline Auckland & $\mathrm{a} 64871$ & 1185 & 15.3 \\
Tauherenikau (Wairarapa) & $\mathrm{d} 15134$ & 1109 & 12.7 \\
Blenheim Aero. (Marlborough) & g13581 & 738 & 12.6 \\
Rangiora (North Canterbury) & h32352 & 702 & 11.4 \\
\hline
\end{tabular}

${ }^{1}$ New Zealand Meteorological Station Reference Number.

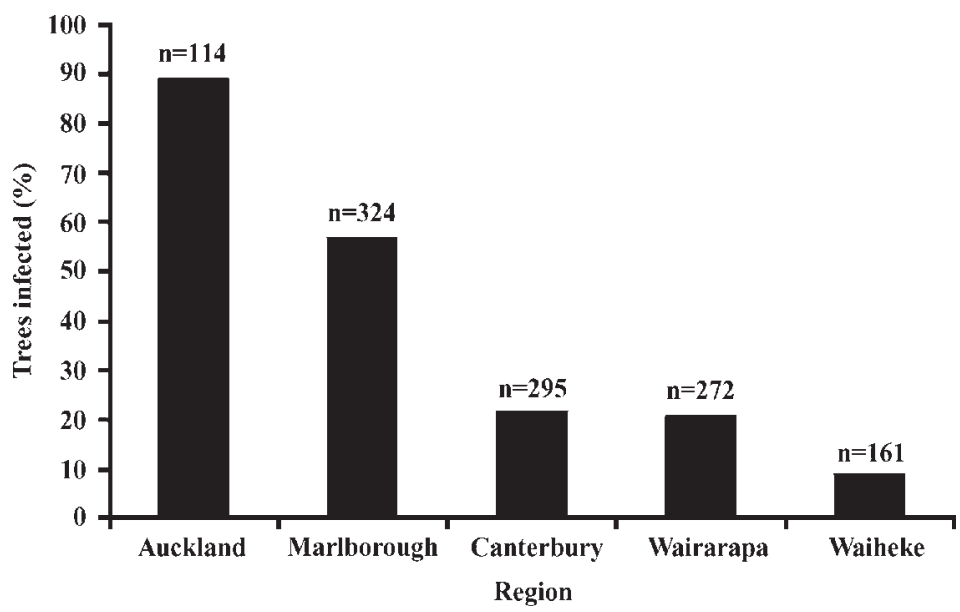

FIGURE 3: Effect of region on trees infected with OLS. Data was pooled across all cultivars and expressed as percentage trees infected from the total number of trees assessed; $n$ denotes the total number of trees in each area. 


\section{Effect of cultivar}

Cultivar had a significant effect $\left(\chi^{2}=87.4, \mathrm{df}=5, \mathrm{P}<0.001\right)$ on the prevalence of OLS, with Souri and Nabali showing the highest prevalence of trees infected, followed by Manzanillo and Barnea, then Leccino and Frantoio (Fig. 4). Since Souri and Nabali are considered sensitive cultivars to OLS infection, these results are not surprising. However, it is noteworthy that, for example, from the 146 Nabali trees examined, 127 trees (or 86\%) are grown in the regions with the lowest prevalence of OLS tree infection, namely Canterbury, Wairarapa and Waiheke Island.

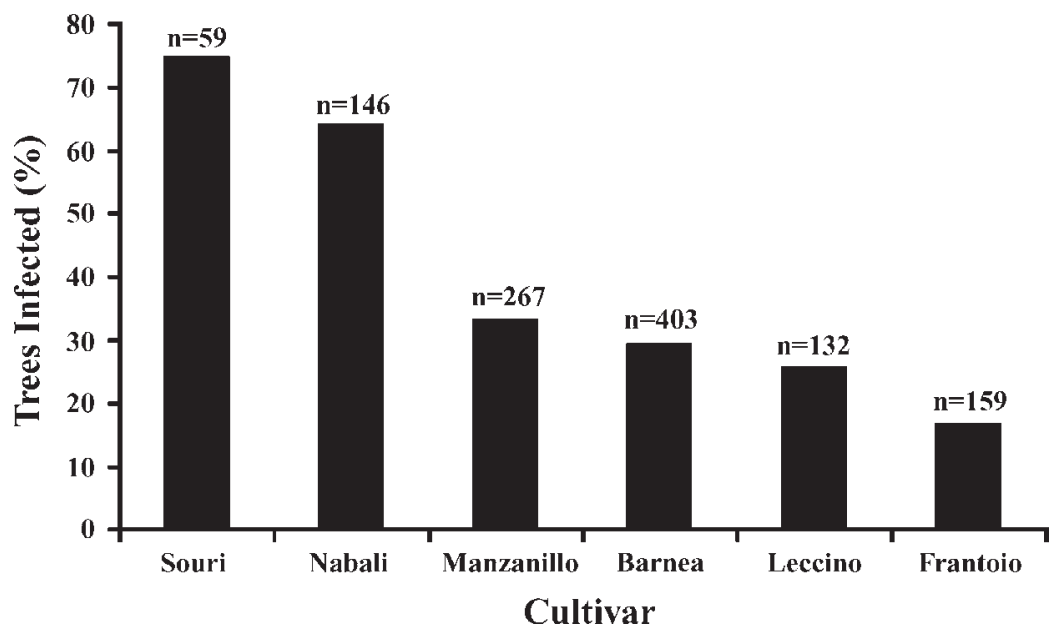

FIGURE 4: Effect of cultivar on OLS prevalence. Data was pooled across all sites; $\mathbf{n}$ denotes the total number of trees for each cultivar.

\section{Severity}

Number of leaves infected per tree, number of lesions per leaf and diseased leaf area were very highly correlated with each other $(\mathrm{P}<0.001)$. Severity measures followed very similar patterns for age, cultivar and region as seen for tree infection. For example, the percentage of leaves infected (Fig. 5) followed a similar trend to OLS prevalence in trees (Fig. 4). The number of OLS lesions found on the leaves depended on cultivar. Similarly, the region where the leaves were sampled from also affected the prevalence and severity of spots on the leaves (i.e. more spots covering a greater area of the leaf were likely to be found in Auckland compared to Waiheke Island).

Assessments of leaf infection indicate that Leccino and Frantoio were less susceptible to OLS than Manzanillo. This agrees with findings reported by López et al. (1999) who assessed resistance of olive cultivars to OLS in Spain. Our findings imply that in New Zealand resistance patterns follow the same trends as overseas. However, the relative resistances/susceptibilities of olive cultivars to OLS requires thorough evaluation for New Zealand environmental and growing conditions. In this study samples were collected at a single time of the year and from the worst affected area of the plant. When the results state that $30 \%$ of the leaves and/or trees were infected, it cannot be concluded that all of the plant was affected at this level, but only the south facing area of the tree that was sampled.

\section{Other observations}

Variation in OLS infection was often observed within a single cultivar in a grove of trees. In general, trees growing in the most sheltered areas of the grove (i.e. next to a hedge or in a hollow) had the highest prevalence and/or severity of infection. 


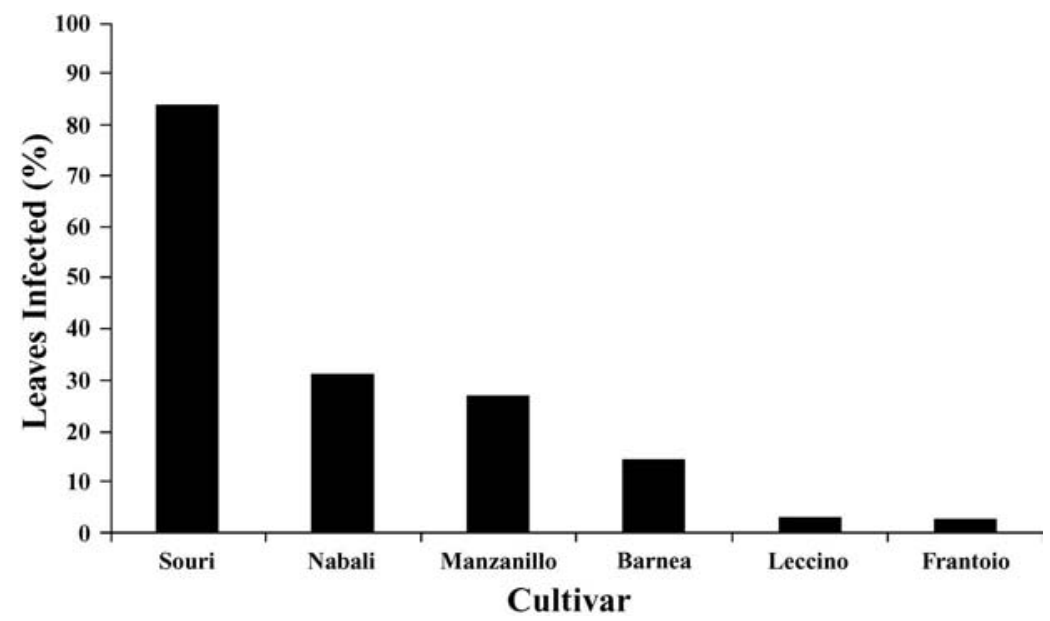

FIGURE 5: Leaf infection from infected trees only. Data is pooled across all sites and tree ages; $n$ denotes the number of trees with OLS for each cultivar.

\section{CONCLUSIONS}

The main source(s) of infection and spread in New Zealand are unknown. One source could be nurseries. Many young trees in isolated sites were infected, suggesting that the pathogen had arrived with the planting material. The nursery environment provides ideal conditions for OLS infection (i.e. overhead sprinklers and shade cloth). Epidemiological studies are required to identify and quantify inoculum sources and to assess climatic conditions for disease build-up and spread under New Zealand conditions. This will then enable targeted control of disease with chemical and/or tree management strategies and development of a disease forecasting system (Viruega and Trapero 1999). The effect of OLS infection levels on tree health, fruit yield and olive oil quality also requires further evaluation.

This survey was conducted during the New Zealand summer season and therefore some limitations should be mentioned: (1) Main infection periods occur during autumn and winter (Viruega and Trapero 1999); (2) following infection, leaves frequently senesce, abscise and prematurely fall to the ground (Graniti 1993); (3) hot, dry conditions during summer reduce infection and/or lesion development (Teviotdale and Sibbett 1995a) and (4) there was a lack of measurements on quiescent infections in this survey. Therefore the survey only provides a preliminary assessment of prevalence of OLS during the summer period of 1999/2000. However, the survey showed that OLS is widespread in New Zealand, with all regions and cultivars affected. Further monitoring is needed to better understand the disease incidence of OLS in New Zealand.

\section{ACKNOWLEDGEMENTS}

We would like to thank the New Zealand Olive Association and Technology New Zealand for jointly funding the survey as part of a Graduates in Research Fellowship (GRIF). We would also like to thank Prof. Don Beaven for facilitating the GRIF and for his editorial comments. Thanks to the researchers Dr Ian Harvey and Mark Braithwaite for advice and help received conducting this survey. The authors further would like to thank the following growers for their help: Andrew Fleming, Barry Wade, Deb and Bill Lyttle, Bruce West, Anne Stanimiroff and Colin Sayles, Gillivray McKay, Helen Clausen, Jack Hobbs, John and Gabrielle Inder, Judy and Barry Rae, Julienne Stretton and Geoff Steven, Ken Prain and Libby Fulton, Malcom and Jill 
Adams, Marlborough Olives, Martin Maguire, Mrs M Redallick, Neal Kunimura and Susan McCarthy, Odelle Sugrue, Paul Williams, Peter Marshall, Ponder Estate, Sandona Olives, Steve Connor, Stu and Maureen Ingham, Tim Day and Tom Willis.

\section{REFERENCES}

Anon., 1980. Summaries of Climatological Observations to 1980. N.Z. Met. Service Misc. Publ: 177.

Azeri, T., 1993. Research on olive leaf spot, olive knot and verticillium wilt of olive in Turkey. Bull. OEPP/EPPO Bull. 23: 437-440.

De Marzo, L., Frisullo, S., Lops, F. and Rossi, V., 1993. Possible dissemination of Spilocaea oleagina conidia by insects (Ectopsocus briggsi). Bull. OEPP/EPPO Bull. 23: 389-391.

Graniti, A., 1993. Olive scab: a review. Bull. OEPP/EPPO Bull. 23: 377-384.

Laviola, C. and Scarito, G., 1993. Observations on spore production in Spilocaea oleagina in southern Italy. Bull. OEPP/EPPO Bull. 23: 411-416.

López-Doncel, L.M, Trapero, A. and García-Berenguer, A., 1999. Resistance of olive tree cultivars to leaf spot caused by Spilocaea oleagina. Acta Hort. 474: 549-553.

Lops, F., Frisullo, S. and Rossi, V., 1993. Studies on the spread of the olive scab pathogen Spilocaea oleagina. Bull. OEPP/EPPO Bull. 23: 385-387.

Shabi, E., Birger, R. and Lavee, S., 1994. Leaf spot (Spilocaea oleagina) of olive in Israel and its control. Acta Hort. 356: 390-394.

Teviotdale, B.L. and Sibbett, G.S., 1995a. Consistent annual treatment helps future olive leaf control. California Agriculture 49: 27-32.

Teviotdale, B.L. and Sibbett, G.S., 1995b. Residual effects of treatment on future control of olive leaf spot disease. Olivae/No. 57: 37-43.

Teviotdale, B.L., Sibbett, G.S. and Harper, D.H., 1989a. Control of olive leaf spot by copper fungicides. Appl. Agric. Research 4:185-189.

Teviotdale, B.L., Sibbett, G.S. and Harper, D.H., 1989b. Several copper fungicides control olive leaf spot. California Agriculture 43: 30-31.

Viruega, J.R. and Trapero, A., 1999. Epidemiology of leaf spot of olive tree caused by Spilocaea oleagina in southern Spain. Acta Hort. 474: 531-534. 